\title{
The Relevance of Legal State Idea in Ensuring the Realization of the People's Welfare
}

\author{
Muhammad Junaidi \\ Fakultas Hukum \\ Universitas Semarang \\ Semarang, Indonesia \\ institut.junaidi@gmail.com
}

\author{
Tatas Tatas \\ Fakultas Hukum \\ Universitas Semarang \\ Semarang, Indonesia
}

\begin{abstract}
The Constitution of the Republic of Indonesia has objectively placed the position of the state of Indonesia as a state of. The implications of this issue must be objectively directed to the question of the extent to which the role of law in the form of maintaining the unity of the Republic of Indonesia. Many studies would be more interesting if they were examined in practice perspectives in developing countries. The findings of the study indicate that the paradigm of law enforcement in Indonesia has been considered as one of the important points in realizing the unity of the Unitary State of the Republic of Indonesia. In practice, it is seen based on the testimony of the extent to which the model of law enforcement and legal studies exist in Indonesia and as a measurement of state existence and state stability in realizing the basic conception of the welfare state. When compared with other countries, it has the validity of truth. Based on this issue, it is necessary to put law enforcement and law in the book as one of the handles of the executive, legislative and judicative in making the main measure of the integrity of the Republic of Indonesia
\end{abstract}

Keywords-- relevance; law, Indonesia

\section{INTRODUCTION}

In our national constitution, it isprimarilystipulated in the Constitution of the Republic of Indonesia, rationally, it is the embodiment of a State that has different characteristics from other countries. The a forementioned matters are Article 1 paragraph 1, paragraph 2 and paragraph 3 of the Constitution of the Republic of Indonesia. Textual descriptions in the Constitution of the Republic of Indonesia are outlined as follows:

(1) The State of Indonesia is a unitary State in the form of a Republic.

(2) Sovereignty is in the hands of the people and carried out according to the Basic Law.

(3) The State of Indonesia is a legal state.

When it is formally examined in the provisions of paragraphs 1, 2 and 3 above, the state order is at least described through the form of pluralism, power of the people, and the concept of the State of law as a social engineering. The form of pluralism can be lived through the paradigm of the Unitary State as a symbol of diversity of species, culture, language and so on that exist in the population in Indonesia. The power of the people indicates that the orientation of the State is present as a form of realization of the desire to prosper society. While the concept of State law becomes the final alternative in achieving that goal all by placing the law as a tool of social change (social engineering).

With regard to the substance of the law, the opinion of Thomas Aquinas stated that the legislation or law is the conclusion of human ratio and which is in the form of volition. Then, in accordance with Cicero's opinion, the law is the principal base and his mind, and which is the command and ratio for public interest[1]. This is what is often understood by a State in the Greece and Roman times, but it changes position when modern times often put the law on the priority of political instruments more dominant rather than placing it in the position of the social change tool (social engineering).

The irrational placement of the law is grounded in the ideas delivered by Niccolo Machiavelli and Jean Bodin who also state that the state's goal is power. His definition of the state is as follows: The state is the whole and the families with all their possessions, led by reason and a sovereign ruler. So like Aristotle, Jean Bodin argued that the family is the origin or foundation of the state, whether by logic or by history. The power of the state requires limiting freedom of action according to nature. In the family there is a pater familiasas the head of the family performs restrictions in the family. Society is the instinct; the basic state is the power. At first there is only one family, then other families join and are a unity, because then they together can defend themselves well. [1]

As a form of conceptualization, the state is an expression of family interests termed as regime interest, the extent to which the law is able to maintain the sovereignty of a State as a whole is one of the realization of the purpose of holding a state. Here, the reorientation of the State is as a form of community power or politics begins.

According to Shang Yang, this characteristic is then analogized as the goal of the state-forming power. For the establishment of this power, there is a sharp contrast to the relationship between the state and the people. This difference is defined as the opposite of one against the other. Shang Yang 
said that if people want to make the strong and powerful country, then he must make his people weak and poor and vice versa, if people want to make strong and prosperous people, he must make his country weak. "A weak people mean a strong state and a strong means a weak people, a country, which has the right way, in concern with weakening the people".[2]

Open minded was also delivered by Hoogerwerf. As his perspective, the state is an organized group, a group with goals that are somewhat under consideration, the division of tasks and the integration of forces. Members of this group are citizens, residing in a certain region. The state has this area of supreme power that is recognized sovereignty. It determines if necessary by force and violence, the limits of power and people and groups in society in this area. This does not diminish the fact that the power of the state also has boundaries, for example due to power and international and supra national bodies. State power is recognized by citizens and other citizens, in other words, the highest authority is authorized the highest. Then there is a leader who is recognized by the state, namely the government. [3]

Some theories above clearly put the presence of law in a State only as a tool of power. It raises problems; can the law as an instrument to maintain the integrity of a State? This problem seems to be not only asked by the college but also in the community. They often question the same issue of sovereignty States taking into account from the perspective of the rule of law.

Through some of the ideas that have been presented directly above, the general objectives expected in this study are as follows:

1. It is expected to understand the position of law enforcement as one of the instruments which can be the basic foundation of strengthening the integrity of the Unitary State of the Republic of Indonesia;

2. It is expected to be the reference material of the government in optimizing orientation policy structurally, cultural and substantive to the position of a law in its capacity as a strengthening instrument and guard the integrity of the Unitary State of the Republic of Indonesia;

3. It is expected to formulate new insights and ideas related to the views of the legal system as one of the instruments of empowering and strengthening the integrity of the Unitary State of the Republic of Indonesia;

\section{METHODS}

Approach method used was socio legal research. The study of socio legal research is a study that "combines" the study of doctrinal law with social studies. This combination is based on the belief that the rule of law never works in a vacuum. Legal rules work in a space full of value systems, dominant interests, not neutral. Therefore, in the study of socio legal research, there is a textual study of the articles in the rule of law. Furthermore, a sharp analysis of whether the rules in the society can realize justice, the stability of life and prosperity in the community. For that reason, social research is conducted for accuracy and achievement of truth based on paradigm. Social research is then biased concluded that the rules of law can provide justice or not.

This type of research uses analytical descriptive research. While the data collected in this study were secondary data consisting of primary legal materials, secondary legal materials and tertiary legal materials. For the data analysis method used qualitative analysis. The qualitative analyst in this case is the work done by working with the data, organizing the data, sorting it into manageable units, synthesizing it, searching and finding patterns, finding what is important and what is learned, and deciding what can be told to others. [4]

\section{RESULTS AND DISCUSSIONS}

The law enforcement scheme in Indonesia with comparison of other countries has given birth to the picture that law enforcement and legal studies become one of the compulsory instruments that must be developed in every country. Several testimonies in published research results in each country between the level of legal understanding and the quality of punishment are correlated to the stability of a country primarily related to crime or crime rates in a country.

One of the results of the study reveals the low level of education which in this case includes the lack of law awareness - it is then referred to as poverty, correlates to the crime rate or high crime rate in the practice of each country. These problems become sub categories of global (social) problems faced by almost all countries including Indonesia, namely poverty problems (including low level of education) or lack of prosperity. The problem of poverty became one of the triggers and causes of criminal acts such as theft. Some important points that can be concluded are: 1. Poverty (including low level of education) has a huge impact on the chances of a crime where high poverty levels indicate difficulties in meeting the needs of life and on the one hand the needs of very much while the tool satisfaction needs are very limited. 2. Poverty (including low levels of education) result in social inequalities and social inequities resulting in social jealousies then resuming in social turmoil and usually ending in social conflicts and the occurrence of a crime. [5]

If the issue is drawn on the legal contribution aspect, the applicable is the extent to which the legal view is exercised. The functions that can be exercised by law in the community are affirmed by 2 (two) things. First is as a means of social control, and second is as a means of doing social engineering as a means of social control. The law has the duty to keep the society in behavior patterns that have been accepted by it. In such an affirmation the law only defends what has become a fixed and accepted thing in society or law as the guardian of the status quo. But beyond that, the law can still perform its other functions, namely with the aim to make changes in the community. Legislation can be seen as a juridical formal activity. In this view, it is seen as an activity to formulate in an orderly manner, according to prescribed procedures, what the will of the people. With increasingly then the measures used to assess the work of the legislature is normative, ie whether he is in conformity with the legal norms that regulate his 
activities. But it can also be approached and sociological angles, which primarily look at the position and role that society provides to the institution. Thus, it will be observed the mutual relationship between the institution and the activities of the legislation with the community in which it resides. [6]

Another thing that needs to be examined is the comparison of existing legal education system in the actualization of law to realize the unity of the unitary state of the republic of Indonesia. If compared with other countries there is a matter of direction and orientation that legal education is still not said maximal in contribution to the integrity of the state.

In relation to today's educational conditions, Tilaar states that national education today is faced with four key crises, which are related to quantity, relevance, or external efficiency, elitism, and management. Furthermore, there are at least eight main problems of the national education system: (1) the decline of morals and morals of learners, (2) equal distribution of educational opportunities and equity of education quality, (3) low quality of education at various levels and types of education, (4) ) low internal efficiency of the national education system, (5) low external efficiency of education and training systems, (6) educational and training institutions, (7) education management not in line with national development and (8) unprofessional resources[7]. It is no exception in the legal education system in Indonesia.

This is where the need to optimize the contribution in education instrument by taking into accounts the characteristics of educational development in Sudan and in Japan. These two countries prioritize at least three directions of policy taken related to the development of educators and education reflection of the education system in Indonesia, namely:

1. Policies related to the welfare of educators and education personnel;

2. Policies related to the process of procuring and placing educators and education personnel;

3. Policies related to efforts to improve the professionalism of educators and education. [7]

This formulation will certainly make the relevance of education in the field of law in particular as a manifestation of efforts to maintain the unity of the republic of Indonesia. If further the strengthening of the law through the strengthening of legal education becomes a practical form of the instrument to be executed, the legal understanding generated by legal education will be the control of power in making the rule of law and implement the law.

In this case, what needs to be a record is political power, although having the force must still put forward the aspect of the interests of the state or society. Understanding that prioritizes the interests of the state or society is called collectivism. Aristotle's opinion of the order and nature of the state or society is that the state is a unity, an organism that is a wholeness that has its own foundations of life. Thus, the state is always experiencing arises, develops, tides, subsides and sometimes dies; as well as the state of man, beast or plants. [1]
It is almost similar to moral perfection; Locke (16321704) also considered the state as a representation of the will of society as a whole. Locke argues that the existence of power and sovereignty of a king or a state is created, precisely and the result of giving or delegating power and sovereignty mandated by society. The State according to Locke, created by society with the aim of defending and protecting the rights of its citizens and not vice versa, that is to disturb and negate the rights of its citizens or to demand obligations to its citizens. The state is a neutral institution and various interests in a diverse society, and neutral for its own interests. [8]

Things that need to be observed based on the above description, is not able to aspire the state as a form of welfare state, but not hold its relevance against law enforcement and legal education. It is clear that this aspect of legal contribution as part of the fundamental characteristic of the integrity of the state has become a fundamental part of fact or theory of article 1, paragraph 3 in the 1945 Constitution of the State of the Republic of Indonesia.

The relevance of the law in realizing the unity of the state is not only a conclusion in the present era. The view is actually already existed in the twentieth century. In the twentieth century it has been seen that law can be a means of change and engineering (society), compatible with the ideals of the welfare state conception (verzorgingsstaat). That view has produced a large number of rules; sometimes it is a very detailed legislation, sometimes it only in the form of a major law (raamwetgeving). [9]

The most important thing is the extent to which the role of government is encouraged in pursuing it is no longer a goal but a real actualization. Such a principle is at least very necessary to be executed by the executive, legislative and judicial who in his capacity to control the power by placing Law Enforcement and Law in the Book as a determining instrument of the unity of the Unitary State of the Republic of Indonesia [10].

Some cases in Indonesia have become an indication that the more executive, legislative and judicial in placing Law Enforcement and Law In the Book disproportionately more openly the attitude of unity and unity of the injured state [11].

\section{CONCLUSION}

It is as clear as indeed the integrity of a state should be placed on the realm of legislative, executive and judicial roles to strengthen the law both from the aspect of law enforcement and the aspect of legal education. One such implementation is based on the subjective effort of our constitutional doctrine which states that Indonesia is a state of law (art. 1 verse 3 ).

This is where the relevance of Legal Empowerment can be ensured to be the unity of the Unitary State of the Republic of Indonesia. The contribution of law in the integrity of the Unitary Republic of Indonesia should be emphasized on the extent to which the role of understanding the value of capital, justice and legal benefit as a social engineering placed rationally and proportionally. The role of all parties to understand it becomes a basic need for the goal of law enforcement relevance in realizing the Unity of Republic of Indonesia. 


\section{ACKNOWLEDGEMENT}

This study was supported by Universitas Semarang.

\section{REFERENCES}

[1] Soehino, Ilmu Negara, Liberty. Yogyakarta, 1996.

[2] M. Kusnardi and B. R. Saragih, Ilmu Negara. Gaya Media Pratama, Jakarta, 1994.

[3] I. K. Syafiie, Sistem Pemerintahan Indonesia. Rineka Cipta, Jakarta, 1994.

[4] L. J. Moleong, Metode Penelitian Kualitatif. Bandung: Remaja Rosdakarya, 2010

[5] Prayetno, "Kausalitas Kemiskinan Terhadap Perbuatan Kriminal
(Pencurian)," J. Univ. Negeri Medan, Media Komun. FIS, vol. 12, no. 1,2013

[6] R. Sadjipto, Hukum dan Masyarakat. Angkasa, Bandung, 1980.

[7] Suraijiah, "Pengembangan Tenaga Pendidik Dan Kependidikan Di Negara Jepang Dan Sudan,” J. Ta'limMuta'allim, vol. III, no. 6 , 2013.

[8] S. Mansyur, Negara dan Korupsi. Yayasan Obor, Jakarta, 2008.

[9] J.A Pointer, Penemuan hukum Jendela Mas Pusaka-Anggota Ikapi, Bandung. 2008.

[10] Rifqi Ridlo Phahlevy, Mochammad Tanzil Multazam. The Shifting Of Village Autonomy Concept In Indonesia. https://dx.doi.org/10.17605/OSF.IO/Z8288

[11] Phahlevy, R. (2016). The Concept of Village Autonomy in Indonesia (Indonesian Constitution Perspective). Rechtsidee, 3(1), 27-40. doi:http://dx.doi.org/10.21070/jihr.v3i1.151 